\section{CZETTER Ibolya}

Eötvös Loránd Tudományegyetem

Savaria Egyetemi Központ

ORCID: 0000-0001-9548-9547

czetter.ibolya@sek.elte.hu

\section{A „megkötöttség” vagy a távozás verse? Ambivalenciák és paradoxonok Ady Sípja régi babonának címú versében}

A dolgozat az újraolvasás és újrakontextualizálás jegyében Ady Sípja régi babonának címü versét értelmezi, a nyelvi megformáltság összetevőire koncentrálva. Arra a kérdésre keresi a választ, hogy a nyelvi megformáltság összetevői felől milyen fontosabb, életművet, müfajt, líraelméleti kérdéseket, a korszerü Ady-képet is érintő összefüggésekre láthatunk rá, mi újat, fontosat képes mondani egy-egy újraolvasott szöveg. A tanulmány a paradoxitás életmúben betöltött szerepéből kiindulva, a paradoxon versbéli múködésének alakzati, figurális, szerkezeti kérdéseit járja körül, müfapoétikai és verstani szempontok bevonásával.

Kulcsszavak: Ady Endre, újrakontextualizáció, alakzatok, paradoxon, szerepvers

„Aki valamely költőt legmélyében megérteni akar, annak elsősorban a nyelvét kell tanulmányoznia" - idézi Babits egyik, Adyról szóló tanulmányát a költő máig legmeghatározóbb monográfusa, Király István (Király 1982). S mintha az Újraolvasó-sorozat részeként napvilágot látott kötet, az Ady-újraolvasó is a nyelvi reflektáltság szempontjait tartaná a legfontosabbaknak: „Ady lírája is csak akkor élő hagyaték, ha új önmegértésben részesíti a jelent, (...) az Ady-művek új(ra)értelmezése szükségszerűen e szövegek nyelvi létmódja szerint válhat csak történéssé." - olvashatjuk a kötet előszavában (Kabdebó et al. szerk. 1999: 7). Tény, hogy az Ady-líra megszólító ereje épp a befogadói ízlés átalakulása miatt változott sokat az utóbbi évtizedekben, Petőfi és József Attila mellett mégis ő az egyik legismertebb, legnagyobb hatású lírikusunk. A kutatást, a szakmai érdeklődést pedig ébren tartja, inspirálja, hogy az életmű értése az irodalmi modernség megértésének is feltétele.

Az újraolvasás és újrakontextualizálás engem is arra sarkall, hogy az általam fontosnak tartott és ismert Ady-versek kanonizált olvasási gyakorlatát felülvizsgáljam, s válaszoljak arra a kérdésre, hogy a nyelvi megformáltság összetevői felől milyen fontosabb, életművet, műfajt, líraelméleti kérdéseket, a korszerű Ady-képet is érintő összefüggésekre láthatunk rá, mi újat, fontosat képes mondani egy-egy újraolvasott szöveg. Mivel a kortárs líra és versértés horizontján is megszólíthatónak látjuk Ady bizonyos költeményeit, sőt a kuruc líra avultnak tetsző paradigmája például újabban a költői közgondolkodás formálójának is mondható, egy sokak által alapos elemzésnek alávetett kuruc verset, a Sípja régi babonának címüt választottam újraolvasásra. Az 1913 márciusában keletkezett vers a Ki látott engem? (1914) kötetben a Sípja régi babonának, azonos címú ciklus darabjaként látott napvilágot. A verset leginkább a szövegszervező alakzat, a paradoxon működésének szempontjából értelmezem. Az ellentmondásokat Ady egész életművét fémjelző alakzatként tartják számon, valószínűleg közel állt drámai alkatához, 
mindig szélsőségek közt egyensúlyozott, e versben sem csupán alakzati, figurális, szerkezeti szinten jut szerephez, hanem globálisan, az életmű egészét érintő kérdésekkel összefüggésben.

\section{A paradoxitás szintjei}

Ady úgynevezett „kuruc-verseinek” az életmüben betöltött szerepe

A vers kapcsán az Ady-líra hagyományhoz való, ellentmondásos viszonyára is kitekinthetünk.

Ady verseinek középpontjában gyakran nemzeti sorskérdések állnak, közösségi költőnek is tekinthető, sokszor lépett fel egymásnak ellentmondó ideológiák képviselőjeként, ugyanakkor az individualizmus elkötelezettje is volt, s e kettősség nyelvében, stílusában is tetten érhető.

A kuruc versek az újító, modern jelzőkkel felruházható költőt a hagyomány világához kötik. De miért is fordult ezekhez a témákhoz, s mi az, ami ezzel kapcsolatban oly sokáig, szinte élete végéig fogva tartotta? Elsősorban azért, hogy a több évszázados hagyomány képviselőjének, méltó utódának pózában tetszeleghessen, másodsorban, hogy a maga korának aktuális kérdéseit, a nagy dilemmákat, kritikákat megfogalmazhassa. (Sajnálatos, hogy sok, akkor időszerű gondolat nem bizonyult napi érdekűnek, még ma is tanulságokkal szolgál). A versek a kuruc költészeti hagyomány továbbélését képviselték, amelynek nagy kultusza volt a 19-20. század fordulója tájékán, olyannyira, hogy Thaly Kálmán és Endrődi Sándor szöveghamisítással kísérleteztek, amiből aztán az elhíresült „dalpör” lett. Ugyanakkor ennek az örökségnek a problematikusságát, a tradíció megszakadásának tragikumát is érzékelte, s a saját felelősségét és megváltozott szerepét próbálta tisztázni a bujdosó megszemélyesítette figurában.

Az e csoportba tartozó versek általános jellemzőit Tverdota György így összegezi: „A versekben szereplő és beszélő alakok olyan harcosok, akik Rákóczi érkezését várják, akik a fejedelem seregében a labancok ellen harcolnak, vagy akik a vesztes szabadságharc után a bujdosók keserű kenyerét eszik. (...) A versek hősei fegyveresen állnak elénk, még ha ez a fegyver csak egy rossz kard is. Gyakran lovon ülnek, s ha történetesen gyalogosan járnak, annak jelzésére a költőnek mindig külön gondja van. A versekben sűrűn említik a kuruc vezérek nevét Rákóczitól Esze Tamáson és Bottyán vezéren át Bercsényi marsallig és a »lőcsei brigadérosig«. Az ,Esze Tamás komája’ című versben három, a kuruc kort idéző szimbolikus helyszínre: Bécsre, Munkácsra és Váradra bukkanunk. ,Az utolsó kuruc'-ban a repertoár Pozsonnyal, Tordával, Budával, Moldovával és Majlanddal egészül ki. A sorból »Kézsmárk hegye, Majtény síkja«, majd Lengyelország és Rodostó sem maradhat ki. De a szimbolikus helyek is sorra feltünedeznek: az árokpart, a »nagy erdők aljai«, a »bujtató lápok«, a nád, a gaz, a sár, a »koldus-vásár közepe«, az idegen lovak taposta porta, a tábortűz. (...) Ady kuruc verseinek egy része dialogikus jellegű, s bennük a harcostársak és sorstársak familiáris megszólítása mindig nagy hangsúlyt kap. A szereplőket leggyakrabban »bujdosó kurucokként«, »utolsó kurucként«, tehát harcos voltukban határozza meg." (Tverdota 2006: 35) A tanulmány vitába száll a Király István képviselte koncepció néhány elemével, s kiemeli: Adynak a legtöbb kuruc verse a bujdosók reményvesztettségét, csalódását, kisemmizettségét mutatja be, panaszos, dacos, átkozódó vagy épp fohászt magába foglaló hangon.

Az említett politikai, történelmi helyzethez kötődő aktualizáláson túl miért is volt fontos Ady számára a kuruc versekben megalkotott szerep? Köztudomású, hogy költői gyakorlatában 1912 körül fordulat áll be, amikor a teljességre törekvéstől való elfordulását, a viszonylagosság-élmény felismerését és a hagyományokhoz való viszonyának újraértékelését látjuk. Léthelyzetének metaforáit tehát a szabadságharc bukását követően buj- 
dosósorsra jutott katonákban látta, akik jó ügyet szolgáltak, küldetéssel bírtak, de becsapottá, számkivetetté váltak. Azért volt fontos tehát ennek a szerepnek a megalkotása, hogy „ebben a verstípusban (vagy ebben is) hangot adjon a szerepvesztés élményének, a feleslegesség-érzetnek. Éppen ezekben a darabjaiban jut legmesszebbre a mandátum nélkül élő ember alakjának kimunkálásában, akit abban a fájdalmas és kétségkívül drámai pillanatban állít elénk, amelyben küldetésétől megfosztották, vagy amelyben ráébred arra, hogy állítólagos küldetése csak üres illúzió volt, hogy nem egy szent ügy hőse, hanem egy történelmi játszma balekja. Ady kuruc-verseinek döntő többségét a perspektíva-vesztés, a becsapottság, az eltévedettség érzése uralja." (Tverdota 2006: 38) A kuruc egy végérvényesen elveszett ügy képviselője.

Utazásvers, létvers, számvetésvers, sorsvers, magyarságvers, kurucvers

A vers tematikai alapon a számadásversek, a magyarságversek körébe tartozik, alapmetaforája az út toposz, amely áttételesen jelenik csak meg, erre utal a bujdosó magyar éneke alcím, illetve a versbeszédben feltűnő szimbolikus terek, az implikációk, valamint a pragmatikai kontextusból a folyamatos eltávolodásra következtethetünk (sátor-sarkon, menőben, Fáradt lábbal útrakészen, Üzenhettek már utánam, Határ szélen botot vágok, Sohse nézek többé vissza). A toposz és a verstípus összekapcsolódik, hiszen a legtöbb verse életköltemény, amely a lét értelmére kérdez rá. Ady költészetét át- meg átszövik a különböző utazások, az út toposza nagyon sok versében szerepel. Az utazás a környezettel való állandó konfliktusnak is metaforája, az elválás, az elszakadás pillanata jelentette a szimbolizálódásra hajlamos helyzetet (El a faluból, Elüzött a földem, Párizs az én Bakonyom). A közösséghez tartozás vágya és a nonkonformista, beilleszkedésre képtelen természet kettőssége munkált benne, hasonlatosan a szülőföld-élményéhez. Városi ember volt, de élt benne a falusi élet, a béke, a megnyugvás utáni vágy, nosztalgia. Distanciát érzett, tudatalattija azonban visszavágyott a védettségbe. Hazaszeretete paradoxonokkal, ellentmondásokkal teli, szorongásos érzés: sírva vigadó, ostorozva becéző, végletekbe csapó patriotizmus. A megtagadásban azonosulni kész, az azonosulást viszont vonakodás kíséri. Föl-földobott kőként egyszerre akar menni és maradni, elszakadni és visszahullni. A szülőfölddel kapcsolatos élménykör, a tágabb és szűkebb haza gondolatköre is kapcsolódik tehát a vershez, anticipálva minden olyan költeményt, amely ennek az ambivalens érzésnek ad hangot: például az Elsüllyedt utak és a Kocsi-út az éjszakában című versekben. Ez utóbbi a legismertebb távozásversek egyike, amelyben a világ szétesettségének végérvényességére döbben rá.

\section{A lírai szerep kérdései / Szerepvers-problematika - líraelméleti dilemma}

A verssel foglalkozó szakirodalomban az egyik legtöbbet vitatott kérdés, hogy ki is az a persona, aki a vers beszélője? Hogyan konstruáljuk meg azt a személyt, aki a bujdosó magyar szerepében tűnik elénk? Mégiscsak a stílusjegyek - a pátosz, a lelkesültség, a heroikusság vagy a kiábrándulás, a lemondás, a magatartásban megragadható sajátosságok, és mindenekelőtt a vers valamilyen nehezen megragadható lendülete vagy erőteljessége - segítségével képződik meg a versolvasóban az a légies személy, aki a versben beszél. Rakovszky Zsuzsa egyik írásában hosszan foglalkozik az én megkonstruálásának lehetőségeivel, s M. H. Abrams amerikai irodalomtudós definíciójára támaszkodva így határozza meg a szerepvers fogalmát: „1. A versben mindvégig egyetlen személy beszél és ez a személy nyilvánvalóan nem a költő -, egy jól körülírható helyzet különleges pillanatában. 2. Ez a személy egy vagy több másik személyhez beszél, illetve párbeszédet folytat velük, de a hallgatóság jelenlétéről és arról, hogy ők mit tesznek vagy mondanak, 
csak a beszélő szavai árulkodnak. 3. A beszélő alakjának kiválasztásában és megformálásában elsősorban az vezérli a költőt, hogy igyekszik minél jobban érzékeltetni az illető személy jellemét és érzéseit, méghozzá oly módon, hogy ez minél inkább fölkeltse az olvasó érdeklődését." (Rakovszky 2010: 287)

A költő és a versben beszélő szereplő énje közötti kapcsolat többféle módon alakulhat: van, hogy meglehetősen nagy távolság van a két én között, vannak aztán olyan szerepversek is, ahol a választott szerep nem ellentétes a lírai énnel, hanem csak jobban kiemeli annak valamely fontos tulajdonságát. S vannak olyan szerepversek is, amelyekben a beszélő személyisége szintén nem esik messze a költőétől, viszont eltér tőle nemét, életkorát vagy más fontos tulajdonságát tekintve, ami lehetővé teszi a költőnek, hogy az eredeti empirikus személyiségtől idegen élethelyzetekbe képzelje magát, és ennek segítségével friss, a költészetben még elhasználatlan anyag kerüljön a versbe.

A ki beszél? kérdését a korábbi recepció a szerzővel való azonosítás ideologikus elemzői mozzanata alapján leegyszerüsítette, megállapítván, hogy Ady esetében a teremtett beszélő olyannyira nem áll messze attól a figurától, akinek szerepét magára ölti, hogy voltaképp alakmásnak tekinthető: Király István szerint a kuruc motívum a népiség összegző képi motívuma, „Rajta keresztül fogalmazódott meg legteljesebben a nyelvistiláris népiségben ható tartalmi mondandó: a közösségi felelősségérzés" (Király 1982: 622) A kuruckép az irodalomtudós vélekedése alapján nem véletlenszerü, hanem az egész életművön látensen végigvonuló jellegzetesség. Bár mindösszesen 15 olyan verset írt Ady, amely a kurucversek tematikus csoportjába tartozik, számuk valójában jóval több annál, ha a motivikus érintkezések, a stiláris, pragmatikai kontextus vagy a paratextuális utalások alapján soroljuk be a verseket. „Bennük nem egyszerűen egy történelmi korszak és annak szereplői, vagy éppen egy meglévő szöveghagyomány és annak formakultúrája idéződik meg, de a kurucság történelmileg kódolt viselkedésének (mint amilyen például a bujdosás), habitusának (kesergés vagy ellenkezőleg, heroizáló magatartás) stb. metaforizációja révén egy olyan tág szövegkorpusz körvonalai sejlenek föl, amelynek holdudvarába a kuruc kori figurákat, eseményeket megjelenítő verseken kívül más tematikus (például a magyarság-versekkel kapcsolatba hozható) vagy tematikusan »nem rögzített«, ám modalitását tekintve »rokon« szöveg is beletartozhat." (Herczeg 2014: 670)

A kuruc versek általános jellemző jelzője a régi, hiszen az archaizálás, a történelmi távlatteremtés, a múlt maszkjának felöltése a meghatározó sajátosságuk, valamint a marginalizáltság, a kitaszítottság, a társadalmon kívüliség, a csavargás; a rongyos, szegény, pikáró életforma alakjai egytől egyig. Nem véletlen, hogy a bujdosók olyan díszletek között jelennek meg a versekben, amelyek határhelyzetben, sarkon, valamilyen földrajzi tér szélén, peremén helyezik el őket. Ezek a szcenikus kódok a nyelvi és ritmikai, formai jellemzőkkel kiegészülve alkotják a szerep összetevőit. Király ebben a hősben az ontológiai és antropológiai válság megnyilvánulását látja, s mindezt polifonikusan, mert egyszerre van benne a távlattalanság, a nihil és azzal feleselve a közösségi létbe való visszatérés vágya. A távlatvesztés az eltévedés-érzéssel függ össze, s velejárója a magány, a bezárulás. A közösségi tudat pedig abban nyilvánul meg, hogy a hős közösségi hangon, a közösségért érzett felelősségtől áthatva szólal meg, s gyakran párbeszédet, drámai dialógust folytat egy másik féllel. Ezek a társadalomból kitaszított lények az emberi sors kilátástalanságának tudatában, de a népért való elkötelezettség vagy küldetéstudat terhével vágnak neki a világnak. E verstípushoz kapcsolódóan és az ambivalens 
magatartással összefüggésben alkotta meg Király István a mégis-morál terminust, amely köztudottan a nihil ellenére kimondott igen, a csak azért is kiállás, a megőrzött tartás kifejezése. A monográfia tanulsága szerint a mégis-morál képviselői voltak Ady költészetében a bujdosó kurucok (Király 1982: 626). Némileg túlzó szimbólumává váltak minden nemzeti és nemzet feletti erénynek, amely a reménytelenségben való helytállást, a meg nem alkuvást, a küzdő hozzáállást hirdette.

A mai recepció egyik jeles képviselője, Palkó Gábor a kuruc versek hagyományokkal való kapcsolatát vizsgáló tanulmányában szintén megerősíti a szerep és a mögöttes én között létesülő közvetlen habituális kapcsolatot, kijelenti, hogy „A kuruc költészet és Ady verseinek tematikai, poétikai vagy ritmikai hasonlósága a szerzői szubjektum mentalitásbeli hasonlóságára vezethető vissza." (Király 1982: 626) A költőben ugyanis a protestáló, kuruc tiltakozás szelleme alkati adottságként élt, amely eggyé vált a nemzeti karakterben is fellelhető virtussal, s a kuruc költészet formáit, hangulati-képi világát aktuális érzések kifejezésére használta fel. E felfogásban tehát az önidentifikáció terepeként szolgáltak a kuruc versek.

A vers poétikai megalkotottsága mások szerint túlmutat az azonosság csupán habituális alapon kimutatható magyarázatán. Herczeg Ákos mutat rá, hogy az utóbbi évek recepciójában líraelméleti dilemmaként merült fel a szerep olvasásának a kérdése, a korábbi értelmezők ugyanis nem számoltak azzal, hogy a vállalt vagy felöltött szerepet is szerepként élheti meg a szerző. Felhívja a figyelmet arra, hogy a hagyomány követőjének tételezett költő maga is újraértelmezője a tradíciónak, Ady tehát nem a kuruc líra hiteles továbbörökítője, hanem pastiche-alkotó, „aki rendszerint nem törekszik leplezni a megteremtett hang imitált jellegét, sem mindenestül felszámolni az időbeli elválasztottság nyomait. A kortárs recepcióban a tágabb Ady-értést is meghatározó feladattá válik annak a kérdésnek az eldöntése, hogy a művek beszélője/i szerzői alakmásként ismerhető(k) fel, vagy ellenkezőleg: a szereplétesítés befogadói oldalról bizonytalannak mutatkozó poétikai aktusa valójában az én (a korai költészetben látszólag megdönthetetlen) stabilitása ellen hat - többek közt azáltal is, hogy a beszélő(k) már eleve egy arc nélküli szöveghagyomány idézet(t)-jeként vannak jelen a vers terében" (Herczeg 2014: 673)

E termékeny és teoretikusnak tűnő vitában azt az álláspontot képviselem, hogy a kurucság/kuruckodás - paradoxonnal élve - szerepromboló identitásminta lehetett Ady számára. Nyilvánvalóan tematikus, szimbolikus érintkezésekről van szó, és semmiképp sem a lírai énnek a szerző személyével való bármiféle összemosásáról, hiszen a versek teljes mértékben ellenállnak mindenfajta ilyen összefüggést erőltető értelmezésnek (Király 1973). ${ }^{1}$ A küldetésében, szerepében csalódott, eltévedt és becsapott ember példázatát látta a menekülő kurucok sorsában, s nem a hősies, dacos-gőgös magatartás képviselőit. Nem volt mire fel dacosnak, mégis-morálosnak lenni a veszett ügy vesztes katonáinak (Király 1973).

A Sípja régi babonának azért tekinthető egészében paradoxonnak, mert a lírai én a közösséghez való viszonyában a távozás, a hazaelhagyás mellett dönt, miközben retorikája és a vers poétikai eszköztára ennek ellenkezőjét: a maradást, a kötődést, a ragaszkodást konnotálja. Szemantikailag-tartalmilag tehát a belső meghasonlás formai kifejezője. A szövegszinten ható ellentmondásosság sok bizonytalansággal, nehezen szemanti-

\footnotetext{
${ }^{1}$ A tanulmány lát összefüggést Ady életének eseményei és a versben bujdosni készülő lírai alany figurájában. Ezt veszi át Szilágyi Péter Ady Endre verselése címú monográfiájában.
} 
zálható részlettel függ össze, ezáltal is növelve a versjelentés nyitottságát, polifóniáját, a feloldhatatlan feszültség érzését.

A versben a hazáját épp elhagyni készülő/kényszerülő bujdosó magyar énekét halljuk, akit szélsőséges és ellentmondásos lelkiállapotban, panaszos beszédaktusát hallgatva találjuk a versindító helyzetben (Kölcsey paradoxonát kölcsönözve: aki „nem lelé honját a hazában”): „sírom sorsod”, „menőben bús világgá”, „Fáradt lábbal útrakészen”. A bujdosóra váró bizonytalanságot és hiábavalóságot a tág jelentéskörrel bíró „bús” jelző hordozza, illetve feszültséget kelt a "fáradt lábbal útrakészen" paradoxon is, jelezve és érzékeltetve a távozó kényszeredettségét. Mintha csak az Elindultam szép hazámbul kezdetű népdalt idézné a vershős magatartása. A vásárban bort nyakaló cselekvés is inkább az elkeseredésében lerészegedő, a mértéket elvesztő, a sírva vigadni akaró, tipikusan magyaros mentalitásnak tartott mintát követő ember képét idézi némileg önironikusan. ${ }^{2}$ A vásárban fülét sértő muzsika hangjai azt a babonát, átkot fújják, amelynek eredetét nem ismerjük, de amely minden magyar számára evidencia, hiszen közösségi tévhit, s valószínűleg a hozzá tartozó átok is közösségi fogantatású lehet. Mi is ez a versbe foglalt, felidézett, a hangszer által megénekelt, hangot kapott babona? Mi az üzenete? A lesújtó nemzeti önkritika megfogalmazása, a nemzetkarakter jellemzése: „Uralkodást magán nem tűr// S szabadságra érdemetlen// Ha bosszút áll, gyáva, lankadt// S ha kegyet ád, rossz, kegyetlen." Olyan bűnök ezek, amelyek jogos következménye, büntetése az átok, az Úr verése. S ami után a bujdosónak egyértelműen hátat kell fordítania, meg kell tagadnia, el kell hagynia hazáját, véreit, fajtáját.

A fülébe csengő sorok idézetként épülnek be a vers beszédstruktúrájába, ez alkotja a harmadik versszakot, majd ezt követően változik meg az egyén és közösség sorsának egymáshoz való viszonya. Jelentéstulajdonításom alapján a beszélő feltehetően a saját énekének hangját ismeri fel a síp hangjában, vagy megerősíti a babona abban az elhatározásában, hogy ki kell lépnie a nemzeti közösségből. Az utolsó sorok, mint ismeretes, a kuruc hagyomány tipikus rímszavait kötik össze: issza-vissza, utalnak az ismert népdalra: „Ki a Tisza vizét issza, vágyik annak szíve vissza”, ezzel az áthallással is nyomatékot adva a visszasóvárgásnak. A leghangsúlyosabb helyen lévő szó a vissza, ráadásul rímhelyzetben szerepel, ezért a kontextustól is függetlenedik, önmagában hangzik, pedig a szövegkörnyezet épp az ellenkezőjét állítja: „Sohse nézek többet vissza.”

\section{A lírai én szerepkettőssége}

A versben a lírai én megkettőződése figyelhető meg (egyetértve azon elemzőkkel, akik a versben a kettősséget, s nem az egységes alany jelenlétét képviselik, mint pl. Király). Az alcímben a szerep felvételének aktusa tematizálódik, valamint a bujdosóénekek nyelvi kifejezőeszközeit és magatartásmintáit (sírás, siratás, a közösség megszólítása stb.) is megelőlegezi: Bujdosó magyar éneke.

A vershelyzetben megjelenő egyik alany tehát egy, a népéért, származási közösségéért felelősséget érző üldözött, aki elkülönülten, magába roskadva, társtalanságra kárhoztatva panaszolja sanyarú sorsát, „magamban sírom sorsod”, s akit (a magamban szó másik jelentését is figyelembe véve) talán senki sem hall, mert magában sír, azaz belül sír.

\footnotetext{
${ }^{2}$ Frazémáink igazolják, hogy a magyar hagyományban megfér egymás közelében a sírás és nevetés, a dudulás (éneklés, mulatás) és a sírás, lásd: Pesti (2016).
} 
(Érdekes, a szerepproblematika szempontjából továbbgondolásra érdemes összefüggés, hogy a sír ige továbbképzett alakja a síp, sipít, sivít alak, mintha csak a sípszó, a címben megnevezett népi hangszer a bujdosó magyar sírásával hangzana egybe, mintha annak kellemetlen hangja sípolna, sipítozna tovább a vásári mulatságban. ${ }^{3}$ ) A versbeli én aztán maga is befogadójává, hallgatójává válik a sípszó hangja által képviselt másik énnek, aki nem kap „arcot” a versben, akinek csak a hangját halljuk. Ez a hang lehet a hagyomány, a babona szólama, amelynek negatív konnotációját a felidézett kellemetlen beszédhelyzet is (f)okozza: „sipol a fülembe”.

Visszatérve az említett kettősséghez, a műfaji hagyomány szerint épp az elválás miatt érzett fájdalom volt a bujdosók keserüségének oka, a távozás fájdalmában épp a hazához való ragaszkodás mértéke mutatkozott meg.

A bujdosó magyar éneke a magára maradás, a nemzetből való kénytelen kiszakadás siráma. A személyiség megbízott szószólója többszörösen is ellentmondásos helyzetbe kerül: kiszakad a közösségéből, a megtartó eleméből, amely integritását adta. S nem marad számára más, mint a kujtorgás, a veszteglés, a bujdosás, a gyökértelenség érzése. A második sorban az aposztrophé alakzata csak látszólagos megszólítás, valójában önmagában, a lírai énben zajlik a dilemma: a belső kötés és a kényszerű eloldás vitája, a kívülről bírált $s$ a belülről oly jól értett helyzet ellentmondása. „Vérem népe, magyar népem” a birtokos szerkezetú ismétlés személyjeles nyomatékos zárása, valamint a szimbólumnak is felfogható szinekdoché (vér) is ennek az elfogultságnak a képi és grammatikai kifejezője. A vers további részében, a 2. versszakban ugyancsak az énen belül (a bujdosó én hangjaként) hallatszik a birtokos személyjeles, bensőséges megszólítás „Édes népem”, amely aztán átfordul szitkozódásba „átkozott nép”, amint a sípszó hangja (a külső nézőpontú vélemény) átveszi a szólamot. Ezután a hallott ének áthatja a versbeli én gondolatait, a dalban megjelenő énnel, a babona hangjával azonosul, így cserélődik fel az elfogult édes a lemondást, lesújtó véleményt magába foglaló veszett jelzőre: „Veszett népem veszett földje: // Sohse nézek többet vissza." A külső perspektíva így belsővé válik, a népért síró magatartásból megtagadás, ostorozás, menekülés lesz. ${ }^{4}$

Az értelmező számára folyamatosan nehézséget okoz a szólamok szétválasztása: nem egyértelmű, hogy a 2. versszakban a megszólítás és az azt követő közlés: „Sohse lesz jól, sohse látlak” a bujdosó önálló hangja-e vagy a sípszó közvetítette dallam hangjának „lefordítása”, esetleg utánamondása. A lírai én hangja, megszólítás „Édes népem” után a „szól a sípszó" közbevetésnek minősül, vagyis, hallom, hogy szól a sípszó is, majd a „Sohse lesz jól, sohse látlak" már a hallottakkal, a régi babonával teljes mértékben azonosuló

\footnotetext{
${ }^{3}$ A sír ige hangutánzó eredetű. Korábban létezett si' 'keservesen sír', 'üvölt', 'zihál', 'sivit' stb. jelentésú ige is, ennek a továbbképzett alakjai közé tartozik a síron kívül a sikit, sikolt, síp, sipit, sivall, sivit, sopánkodik és a süvölt (de a silány, sió - eredetileg 'gyors folyású, zúgó víz' -, sivár, sivatag és a süvölvény is. Bár némán is sírhatunk, a sír igét élettelen dolgokkal ma is használjuk pusztán a hangadás kifejezésére: például hangszerrel, széllel vagy erdővel kapcsolatban.- Még tovább bonyolítja a többértelmú szöveg szerep-problémáját, ha a konstruált hangot, az eddig külsőnek hitt hangot belsőként értelmezzük. Elvégre, ahogy a vershelyzetben megszólaló csak magában sír, a síp hangja is lehet sírásának belső szólama, s ehhez a hipotézishez kapcsolódik a korábbiakban említett sír és a síp szavak szoros etimológiai összefonódása. Ehhez kapcsolódóan meggyőző Herczeg Ákos véleménye: Herczeg Ákos (2014).

${ }^{4}$ A lírai én szólamán belül a megszólítás nyelvi formulájának egységessége, következetes használata is a hangok, szólamok elkülönülésére enged következtetni, a síp, a babona hangja E/3. személyben nevezi meg a "nép”et, amit a beszélő rendre a közelséget érzékeltetve: birtokos személyjeles alakban mond: „népem”.
} 
én hangja (csak feltételezzük, hogy a lírai én szólama egybeforr a hangszer regiszterével, áthangolja saját hangnemét a hallott dallaméra, hiszen ez adhat magyarázatot arra, hogy az „Édes” jelzőből nemsokára „veszett” lesz. Az elválást követő, jövőt előrevetítő sorok („Sohse lesz jól, sohse látlak”) közvetlen folytatásának gondolom a verszáró, szerkezetében is hasonló felépítésű („Sohse nézek többet vissza”) mondatot.

Az énkettőződés az időviszonyok szétválaszthatatlanságát is magával vonja. Nem tudni pontosan, hogy milyen régi babona lép párbeszédbe az irodalmi hagyományt képviselő alannyal, s hogyan kapcsolódnak egymáshoz a különböző időbeli pozíciók. Milyen múltból szólal meg a sípszó hangja, s nem ismert a bujdosó időbelisége sem. De nem is ez a fontos, a lényeges a kulturális hagyományba ágyazottság, a „vérségi” kapocs, a közös sorsban való osztozás, s hogy a babona („átkozott nép// Ne hagyja az Úr veretlen”) él, hat. Ez hozza játékba a hazaszeretet toposzait és a nemzet sorskérdéseivel foglalkozó verseket, azokat a nemzetkritikus kérdéseket, amelyeket Berzsenyi, Kölcsey, Vörösmarty után talán Ady fogalmazott meg a legélesebben.

\section{Poétikai és ritmikai sajátosságok}

A versben nemcsak a polifónia, a sürítés és a drámaiság a feltűnő stílusjegy, hanem a tudatos szerkesztés és a nyelvi formálás nagy feszültsége is szembeötlő. Ezekből mutatok be néhányat: versszakról versszakra haladva, mintegy történetet alkotva bomlik ki az aposztrophékból a lírai alany és a közösség kapcsolatának változása: (vérem népe, édes népem, átkozott nép, veszett népem), az ismétlések révén kiemelt helyzetbe kerülnek a hangsúlyos nyelvi elemek: Vérem népe, majd vérem többé sohse issza; chiasztikus forma hívja fel a jelentésfordulásra a figyelmet: Édes népem, szól a sípszó,// Szól a sípszó: átkozott nép.

A ziláltság grammatikai metaforája az inverziók alkalmazása. Már a címben felfigyelhetünk rá: Sípja régi babonának, kedvelte Ady máskor is a birtokos szerkezetben a birtok előre vitelét, felcserélését. A hagyományos mondatszerkezet felbontása volt gyakran a következménye, ez a megoldás a mindennapi nyelvi változattól eltérést is erősítette, emelkedetté, különlegessé téve a sorok hangulatát: Körös-körül kavarognak // Béna árnyak, rongyos árnyak. A régiesítés a népiesítés eszköze volt, az igeneves tömörítés használata, a latinizmusok alkalmazása ugyanúgy: bort nyakalva, már menőben, sírom sorsod. Valószínúleg tudatosan tette rímhelyzetbe, hogy bevésődjenek a jelentéstartalmukban többletet hordozó szavak: issza, vissza;a negatív konnotációjú fosztóképzőre alapozta a babona tartalmát kimondó három versszak rímelő szavainak összecsengését: veretlen, érdemetlen, kegyetlen. (Egy példa arra, hogy mennyivel egyszerübben, köznapibban hangzott volna, ha felszólító módú, igés mondatba foglalta volna az átkot: Verje meg az Isten! Ehelyett passzív jelentésű igével és körülíró szerkezettel tette archaikus hangzásúvá: Ne hagyja az Úr veretlen). A zeneiség eleve szerepet kap a sípszó által, annak kellemetlen hangja hallik, alliterációk sokasága társul hozzá: sátor-sarkon, sírom sorsod, már menőben, körös-körül kavarognak; A logikai rend felbontásához és a magas fokú sűrítettséghez tartozik még az enallagék szerepeltetése: bús világgá, béna árnyak, rongyos árnyak.

A ritmika felől nézve a vers „ősi” felező nyolcasokban íródott, de ez a kérdés is bonyolultabb ennél. A második strófáig „trochaizált felező nyolcasokban íródott, metrikailag meglepően szabatos: három jambus, tizenhat spondeus, hat pyrrichius és huszonhárom trocheus. Ezután azonban váratlan metrikai fordulat következik: a trochaikus vers tro- 
chaizálhatatlan, tisztán hangsúlyos alakzatra fordul. (...) Ez a gondolati fordulattal társuló ritmikai váltás felezi a verset. Az ilyen szerkesztésmód meglehetősen ritka. A hangváltás általában a vers vége felé vagy éppen az utolsó sorokban vagy sorban, a romantikus szerkesztésmódnak megfelelően kap helyet. Ebben a versben az indokolja a felezést, hogy Ady nemcsak egybefogta saját sorsát a népével, hanem külön-külön is ábrázolta azokat. A kettő egybefogását jól mutatják például az ismétlődő stilisztikai és szintaktikai alakzatok, olyan fontos motívumok, mint a nép, a sípszó, sohse visszatérése - és nem utolsósorban a metrum, hiszen a vers minden sora felező nyolcas. De ugyanilyen fontos a különbözőség is. Itt (...) visszavonhatatlan ítélettel (...) búcsúzik a költő. (...) Az „odi et amo" feloldhatatlan ellentéte feszíti (...) Hiába vált az Ady teremtette szimbólummá, Majténnyá az ország, csak az Endrődi-szimbólum, Kézsmárk hegye magasodik ki abból, hiába az átkozódás és a végleges búcsú: a versből mindezek ellenére érző[dik] az, hogy a költő és sorsa megmaradt földobott kőnek." (Szilágyi 1999: 403-404)

A hosszan idézett részlet ritmikai alátámasztását adja Ady ellentétekbe foglalt, egységet létrehozó múvészetének, $s$ részben magyarázat arra is, mért nem lehet a címben feltett kérdésre egyértelmű választ adni.

\section{Irodalom}

Herczeg Ákos (2014): „Csak magamban sírom sorsod” Közelítések Ady „kuruc-verseihez". Irodalomtörténeti Közlemények, 118(5), 670-682.

Herczeg Ákos (2014): Az én alakzatai a modernség küszöbén : Szubjektivitás és költôiség Ady Endre lírájában. [Doktori értekezés] Debrecen: Debreceni Egyetem

Kabdebó Lóránt - Kulcsár Szabó Ernő - Kulcsár-Szabó Zoltán - Menyhért Anna szerk. (1999) : Tanulmányok Ady Endréről. Bp.: Anonymus

Király István (1982): Intés az őrzőkhöz : Ady Endre költészete az első világháború éveiben 1914-1918. Bp.: Szépirodalmi Könyvkiadó

Király István (1973): A megkötöttség verse. Ady Endre: Sípja régi babonának. Irodalomtörténeti Közlemények, 77(2-3), 277-289.

Takács Miklós (2013): Két kuruc/labanc beszélget : Ady hat, azonos (al)című verséről és a Kovács András Ferenc-féle „átiratról”. In: Mercs István (szerk.): Kuruc(kodó) irodalom: Tanulmányok a kuruc kor irodalmáról és az irodalmi kurucokról. Nyíregyháza: Móricz Zsigmond Kulturális Egyesület pp. 309-325.

Pesti János (2016): Az énekléstől a sírásig: a dudol dudul és a tutul tájszavak összefüggéseiről. Magyar Nyelv, 112 (4), 448-460.

Rakovszky Zsuzsa (2010): Énvers - szerepvers. Holmi, 22(3), 282-289.

Szilágyi Péter (1999): Ady Endre verselése. Bp.: Akadémiai Kiadó

Tverdota György (2006): „Rákóczi, akárki, jöjjön valahára” : Ady Endre kuruc-verseiről. Iskolakultúra, 16(7-8), 34-40.

\section{SUMMARY}

\section{A poem about being bound and/or leaving?}

Ambivalences and paradoxes in Ady's poem 'Sípja régi babonának'

While rereading the poem, the paper offers an interpretation and aims to uncover a set of yet unexplored contextual connections. In the analysis the components of the linguistic 
shaping of the text are foregrounded. In the process of re-reading, several interrelations will be disclosed concerning Ady's oeuvre, the genre, the theory of poetics as well as those that contribute to a more up-to-date evaluation of Ady's poetry. The paper takes its starting point in the role paradoxiality performs in the oeuvre. Various types of paradox as well as the figurative and structural questions it raises are examined in the poem. Theoretical consideration of the genre and poetics will also be taken into account.

Keywords: Endre Ady, recontextualization, tropes, paradox, dramatic monologue 